\title{
In situ bidentate to tetradentate ligand exchange reaction in cobalt-mediated radical polymerization
}

\author{
Anthony Kermagoret, Christine Jérôme, Christophe Detrembleur*, Antoine Debuigne* \\ Center for Education and Research on Macromolecules (CERM), Chemistry Department, University of Liege (ULg), Sart-Tilman, B6a, 4000 Liège, Belgium
}

\section{A R T I C L E I N F O}

\section{Article history:}

Received 28 May 2014

Received in revised form 21 July 2014

Accepted 1 August 2014

Available online 11 August 2014

\section{Keywords:}

Organometallic-mediated radical

polymerization (OMRP)

Cobalt-mediated radical polymerization

(CMRP)

Vinyl acetate

Acrylate

Block copolymers

\begin{abstract}
A B S T R A C T
Organometallic-mediated radical polymerization (OMRP) has seen a significant growth in the last years notably due to the development of new metal complexes, especially cobalt derivatives. Despite of this, none of the reported complexes offers optimal control for monomers with very different reactivity, which somewhat limits the synthesis of copolymers. In order to expand the scope of cobalt-mediated radical polymerization (CMRP), we investigated an in situ ligand exchange reaction for modulating the properties of the cobalt complex at the polymer chain-end and adjusting the C-Co bond strength involved in the control process. With the aim of improving the synthesis of poly(vinyl acetate)- $b$-poly (n-butyl acrylate) copolymers, bidentate acetylacetonate ligands, which impart high level of control to the polymerization of vinyl acetate (VAc), were replaced in situ at the PVAc-cobalt chain-end by tetradentate Salen type ligands that are more suited to acrylates.
\end{abstract}

(c) 2014 Elsevier Ltd. All rights reserved.

\section{Introduction}

Controlled radical polymerization CRP has become an important tool for the preparation of well-defined polymer materials [1-9]. The use of organometallic complexes was a significant step towards the development of CRP of various vinylic monomers [1,9-12]. CRP mediated by transition metal complexes can be classified in two families [13], i.e., atom transfer radical polymerization (ATRP) [14-16] and organometallic mediated radical polymerization (OMRP) $[11,12,17,18]$. The role of the metal center consists in the transformation of the radical species into dormant species through a halogen exchange between the metal center and the radical for the ATRP mechanism (Eq. (1), Scheme 1) [19-21], and in the reversible formation of a metal-carbon covalent bond for the OMRP mechanism (Eq. (2), Scheme 1). In the two cases, the CRP is directed by

\footnotetext{
* Corresponding authors.

E-mail addresses: christophe.detrembleur@ulg.ac.be (C. Detrembleur), adebuigne@ulg.ac.be (A. Debuigne).
}

the redox $M^{n+1} / M^{n}$ properties of the metallic center (Scheme 1) which are highly affected by the coordination sphere [18,22].

Numerous transition metals including nickel [23], titanium [24,25], molybdenum [26,27], osmium [28,29] cobalt [30] and rhenium [31] are effective for ATRP [32]. This family is however dominated by ruthenium [33-35], iron [36-39] and copper complexes [10,21,28,40-44].

Until now cobalt complexes remain the most versatile and efficient controlling agents for OMRP process [11,17]. Cobalt mediated radical polymerization (CMRP) $[45,46]$ is extensively studied especially for its high ability to control the polymerization of a large range of monomers including acrylic monomers [47-50] and vinyl esters $[12,17,46,51,52]$. Depending on the reaction conditions, the CMRP process follows a reversible termination (RT) mechanism (Eq. (2), Scheme 1) [51] or a degenerative transfer (DT) one (Eq. (3), Scheme 1) [53,54]. The latter is observed when the amount of radicals exceeds the amount of cobalt complex. The role of the ligand is crucial and determines the ability of the cobalt complex to control 


$$
\begin{array}{lr}
\text { ATRP } & \mathrm{P}^{\cdot}+\mathrm{X}-\mathrm{M}^{\mathrm{n}+1} \rightleftharpoons \mathrm{P}-\mathrm{X}+\mathrm{M}^{\mathrm{n}} \\
\text { OMRP via RT } & \mathrm{P}^{\prime}+\mathrm{M}^{\mathrm{n}} \longrightarrow \mathrm{P}-\mathrm{M}^{\mathrm{n}+1} \\
\text { OMRP via } D T & \mathrm{P}^{\cdot}+\mathrm{P}^{\prime}-\mathrm{M}^{\mathrm{n}+1} \rightleftharpoons \mathrm{P}-\mathrm{M}^{\mathrm{n}+1}+\mathrm{P}^{\prime}
\end{array}
$$

Scheme 1. Radical polymerization controlled via an ATRP or OMRP process.

the polymerization by affecting the stability of the cobalt-carbon bond of the dormant species, and therefore the active/dormant species equilibrium [12]. Cobalt complexes bearing high electron donating ligands such as porphyrin derivatives [49,55], cobaloximes [56] or 1,3bis(2-pyridilimino)isoindolate ligands [57] (Fig. 1) present high ability to control the radical polymerization of conjugated vinyl monomers such as acrylates. In contrast, low electron donating ligands such as bis(acetylacetonate) (Fig. 1), impart to cobalt an exceptional activity for controlling the radical polymerization of unconjugated vinyl monomers such as vinyl ester, [46,58-60] N-vinyl imidazolium [61], N-vinyl pyrrolidone [62], N-vinyl amides [63-65], and well-defined copolymers of ethylene with vinyl esters and vinyl amides are now accessible [66].

Complex $\mathrm{Co}(\mathrm{acac})_{2}$ presents high abilities to generate reversible dormant species with unconjugated radicals. In the case of vinyl esters and some vinyl amides, DFT modeling showed that an extra-stabilization of the $\mathrm{C}-\mathrm{Co}$ bond occurred via an intramolecular chelation of the cobalt atom with the carbonyl function of the last monomer unit and is responsible for the good control observed (Scheme 2) $[51,64]$.

This intramolecular chelation is made possible by the flexible geometry of $\mathrm{Co}(\mathrm{acac})_{2}[67,68]$ that is not possible for cobalt complexes bearing tetradentate ligands with a rigid square-pyramidal geometry (such as cobalt porphyrins) $[55,69,70] . \mathrm{Co}(\mathrm{acac})_{2}$ is however less efficient for acrylates polymerization as the result of the low stability of the C-Co bond of the dormant species [71]. Controlling the radical polymerization of acrylates by $\mathrm{Co}$ (acac $)_{2}$ is feasible but requires specific conditions that allow to shift the active/dormant species equilibrium towards the dormant ones. It can for instance be achieved by decreasing the polymerization temperature to $0{ }^{\circ} \mathrm{C}$ and by using an excess of $\mathrm{Co}(\mathrm{acac})_{2}$ to force the reversible deactivation of the chain-end [71]. Using more electron donating bis(chelates) ligands such as ketiminato ligands (Fig. 1) instead of acac ligands led to less efficient control over the VAc polymerization [72].

The effect of the type of ligand on the C-Co bond stability was studied by computational calculations of the bond

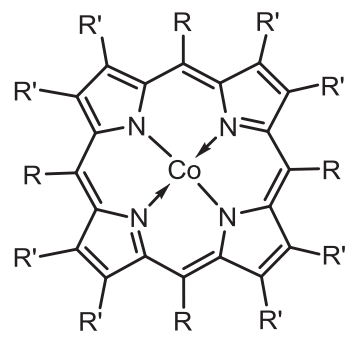

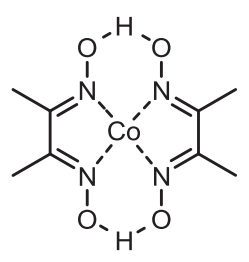

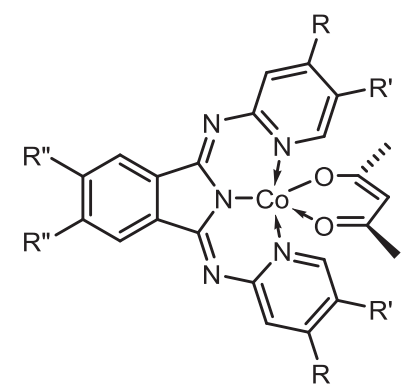

Co(Porphyrin)

Cobaloxime

Co(1,3-bis[2-pyridilimino]-isoindole)

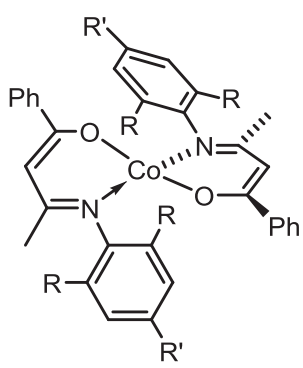<smiles></smiles>

$\mathrm{Co}(\mathrm{acac})_{2}$

Co(Ketimine $)_{2}$<smiles></smiles>

Co(Salen)

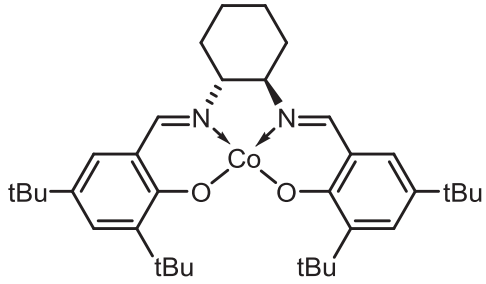

Co(Salen*)

Fig. 1. Cobalt complexes used as controlling agent in CMRP. 


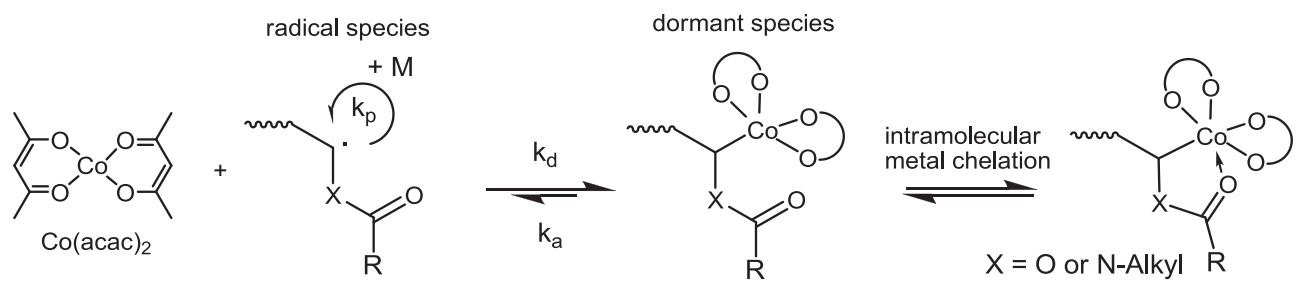

Scheme 2. $\mathrm{Co}(\mathrm{acac})_{2}$-based CMRP of vinyl ester or $\mathrm{N}$-vinyl amide monomers.

dissociation energy (BDE) in various models of dormant species. As an illustrative example, the BDE of $\mathrm{Co}-\mathrm{CH}_{3}$ was evaluated between 40 and $30 \mathrm{kcal} / \mathrm{mol}$ when the cobalt center is coordinated by Salen or dimethylglyoxime ligands $[73,74]$ while this BDE is only $20 \mathrm{kcal} / \mathrm{mol}$ for $\mathrm{CH}_{3}$ $-\mathrm{Co}(\mathrm{acac})_{2}$ [64]. High electron donating ligands stabilize high oxidation degree of the metal center and so, in OMRP process, stabilize $\mathrm{Co}(\mathrm{III})$ dormant species [17]. Considering the BDEs of $\mathrm{C}-\mathrm{Co}$ bond of alkyl- $\mathrm{Co}($ Salen) in the same range than alkyl-cobaloxime complexes [73], these results support the ability of $N, N^{\prime}$-Ethylenebis(salicylimine)-based cobalt complex $\mathrm{Co}$ (Salen) to be adapted for the CMRP of acrylates. In addition, a recent article reported the ability of $\mathrm{Co}$ (Salen) to mediate the CMRP of VAc in a photo-initiation process at $23{ }^{\circ} \mathrm{C}$ but monomer conversions remained low [75]. The same limitation was observed for the VAc polymerization mediated by cobalt porphyrin complexes [76].

In a recent report, Peng and coworkers described the CMRP of both vinyl acetate and methyl acrylate using Cobalt [1,2-Cyclohexanediamino- $N, N^{\prime}$-bis(3,5-di-t-butylsalicylidene)] (Salen ${ }^{*}$ ) (Fig. 1) complex as controlling agent. They reported a good control over the two polymerizations with the formation of polymers with low dispersities (between 1.14 and 1.27) [77].

The addition of neutral ligands, such as pyridine, water, THF, DMF, to the CMRP of vinyl monomers is a route to modulate the reactivity of the cobalt complex and to possibly improve the level of control or the kinetics of the polymerization $[52,67,78]$. This strategy was used to prepare well-defined block copolymers by sequential OMRP of monomers of different reactivity (Scheme 3, route B). For example, the addition of DMF or DMSO to $\mathrm{PVAc}-\mathrm{Co}(\mathrm{acac})_{2}$ chains allowed to properly initiate the acrylonitrile polymerization with the formation of welldefined PVAc- $b$-PAN block copolymers, which is not possible without the addition of the coordinating solvent [68]. It is worth noting that in these above-mentioned cases, these neutral ligands do not substitute the original ones but further coordinate the metal center (Scheme 3, route B).

In the present work, we develop a new approach to modulate in-situ the electronic properties of the cobalt complex at the polymer chain-end in order to adjust the $\mathrm{C}-$ Co bond strength involved in the OMRP process. Bidentate acac ligands are substituted for anionic tetradentate ligands, i.e. Salen type ligands, in a one-pot process (Scheme 3, route C) for improving the block copolymerization of vinyl acetate and n-butyl acrylate (Scheme 4). Prior to investigate the block copolymerizations, the performances of $\mathrm{Co}$ (Salen) for VAc and nBA polymerizations are explored and compared to those of $\mathrm{Co}(\mathrm{acac})_{2}$ and Co(Salen*).

\section{Results and discussion}

2.1. Controlled radical polymerization of VAc and $n B A$ using $\mathrm{Co}(\text { acac })_{2}$ and $\mathrm{Co}$ (Salen): comparison of the system reactivity

The radical polymerization of VAc is initiated by $2,2^{\prime}-$ azo-bis(4-methoxy-2,4-dimethyl valeronitrile (V-70) at $30{ }^{\circ} \mathrm{C}$ in the presence of $\mathrm{Co}(\mathrm{acac})_{2}$ or $\mathrm{Co}$ (Salen) with a $\mathrm{VAc} / \mathrm{V}-70 / C o$ molar ratio of 542/3/1, thus under DT conditions. The monomer conversion and the molecular parameters of the polymers are determined by ${ }^{1} \mathrm{H}$ NMR and SEC, respectively, for samples withdrawn during the polymerization. Whatever the cobalt complex used, an induction period of about $19 \mathrm{~h}$ is observed, suggesting that transformation of the $\mathrm{Co}^{\mathrm{II}}$ in $\mathrm{R}-\mathrm{Co}^{\mathrm{III}}$ occurs roughly in the same extent with both complexes. Afterwards, the polymerization was faster with $\mathrm{Co}(\mathrm{acac})_{2}$ compared to $\mathrm{Co}$ (Salen) (Fig. 2a), indicating a higher tendency of the latter to deactivate the growing PVAc chains. For both complexes, a linear increase of $M_{n}$ with monomer conversion was observed as expected for a controlled radical polymerization (Fig. 2b).

The molar mass distribution $\left(M_{w} / M_{n}\right)$ of the resulting PVAc was lower when using $\mathrm{Co}(\mathrm{acac})_{2}$ (between 1.07 and 1.12, Table S1) rather than Co(Salen) (1.09-1.23, Table S1). In contrast to PVAc produced in the presence of $\mathrm{Co}(\mathrm{acac})_{2}$, size exclusion chromatograms (SEC) of those produced by $\mathrm{Co}(\mathrm{Salen})$-mediated polymerization present a tailing on the low molar mass side which contributes to higher dispersity (Fig. S1). This tailing can be characteristic of fast propagation rate compared to a slow initiation by activation of Co dormant species [71] due to a stable polymer-Co(Salen) bond or to the formation of terminated polymer chains during the reaction. However taking into account the efficiency factors $\left(f=M_{n, \text { theor }} / M_{n, \text { SEC }}\right)$ with $\mathrm{Co}($ Salen) close to 1 (Table S1), irreversible termination reactions of polymer chains seem to be negligible, if any.

Next, we tested $\mathrm{Co}($ Salen) as controlling agent in the radical polymerization of $\mathrm{nBA}$ (nBA/Co molar ratio of $350 / 1$ ) at $30^{\circ} \mathrm{C}$. In this case, 0.4 equivalent of V-70 compared to the cobalt complex is used in order to avoid any excess of radical and to ensure a RT pathway. After a short induction period of time (about $1 \mathrm{~h}$ ), nBA polymerized, leading to PnBA with a molar mass between 70,900 and $141,100 \mathrm{~g} / \mathrm{mol}$, and dispersities between 1.15 and 1.38 (Table 1, Entry 2; Fig. S2). Although the molar masses 


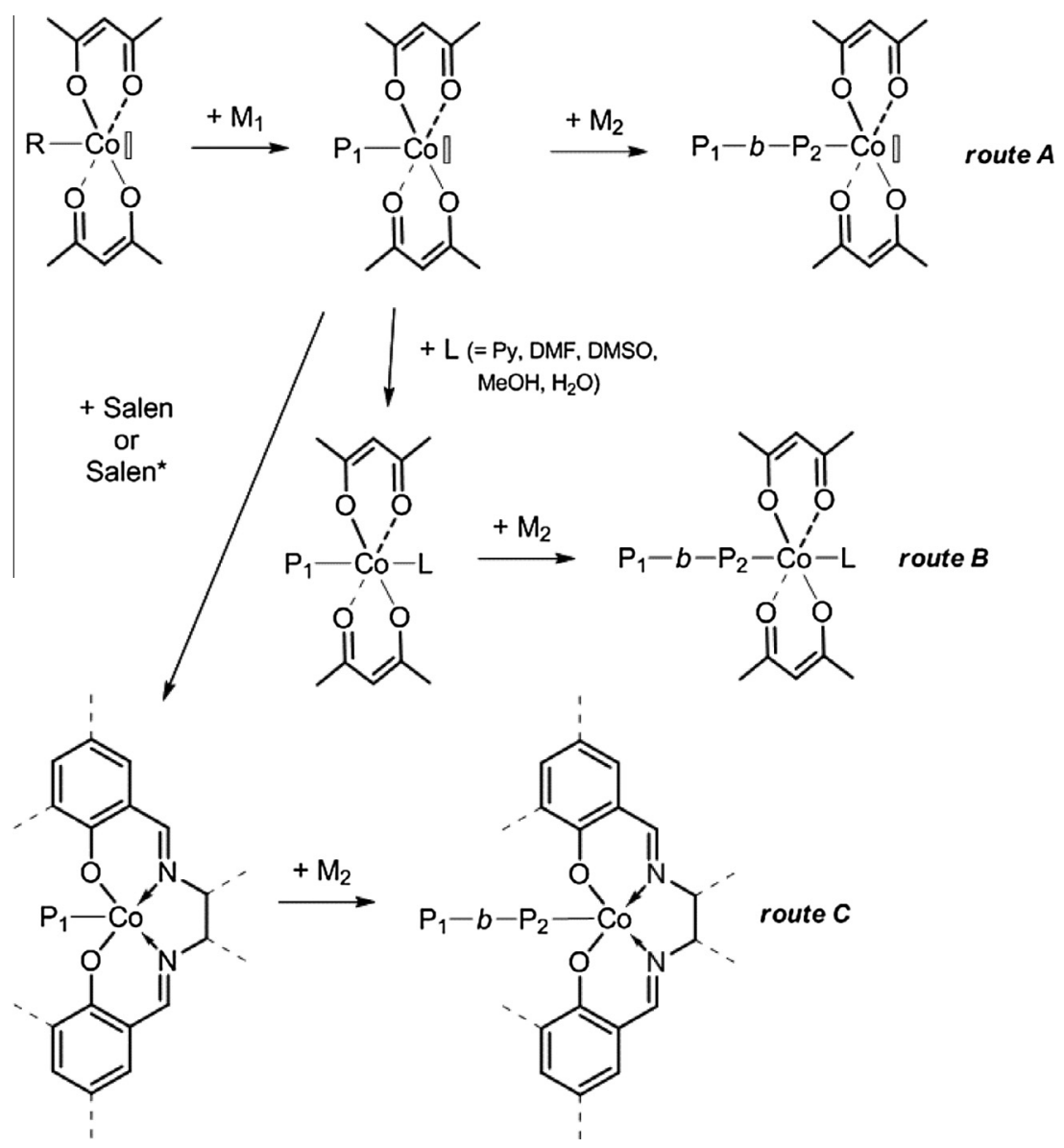

Scheme 3. Sequential CMRP polymerization (route A) as well as addition of neutral ligands (route B) and substitution of the original ligands (route C) of Co to tune the metal center reactivity.

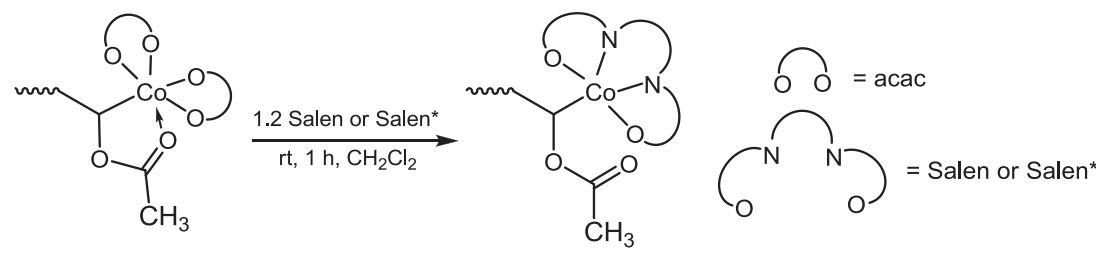

Scheme 4. In-situ ligand exchange to form alkyl-Co(Salen) or alkyl-Co(Salen*) complexes.

increase with the monomer conversion, this evolution is not linear (Fig. S2) and the initiator efficiency factor is low $(f<0.06)$ and is slightly increasing with the reaction time $(f<0.2$ after $4.5 \mathrm{~h}$; Table 1$)$. The control is far to be optimal. Again, dispersity increases with the reaction time due to the presence of a tailing on SEC-curves (Fig. S3). Under the same experimental conditions, $\mathrm{Co}(\mathrm{acac})_{2}$ provides a very fast and uncontrolled polymerization (Table 1 , Entry 1).

The low efficiency factor observed for $\mathrm{Co}$ (Salen) contrasts with the high $f$ values $(\sim 1)$ reported by Peng et al. for the $\mathrm{Co}\left(\right.$ Salen $\left.^{*}\right)$-mediated radical polymerization of methyl acrylate (MA) and VAc [77]. Salen and Salen* present similar metal coordination behavior but the nature of the substituents on the Salen ligand is known to affect the properties of the metal complex, as observed in ring opening polymerization [79]. Recently Shaver et al. reported that electron donating ortho-substituents in Salen*-like cobalt complexes enhanced their efficiency in CMRP of VAc but bimodal mass distributions were observed under the hard experimental conditions employed $\left(120^{\circ} \mathrm{C}\right)$ [80]. To ensure a RT mechanism, the authors used a Co complex/radical initiator molar ratio of $1 / 0.6$. However, low VAc conversions were obtained at $65^{\circ} \mathrm{C}$ [80]. In contrast Peng et al. conducted the polymerization of VAc and MA under DT conditions using a radical initiator/Co molar ratio of $6.5 / 1$ at $60^{\circ} \mathrm{C}$ [77], suggesting a highly stable carbon- $\mathrm{Co}\left(\right.$ Salen*) $^{*}$ bond under these 

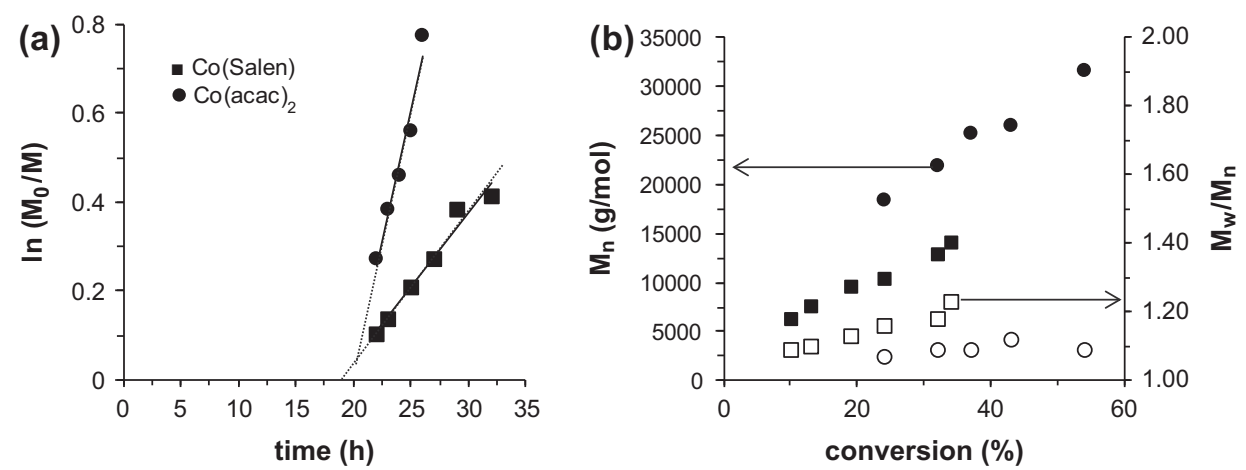

Fig. 2. Plots of $\ln \left([M]_{0} /[M]\right)$ with time (a, left) and dependence of PVAc number average molar mass with conversion (b, filled symbols) and dependence of $M_{w} / M_{n}$ with conversion (b, open symbols) for the VAc polymerization in the presence of $\mathrm{Co}(\mathrm{acac})_{2}(\boldsymbol{\square}$ or $\square$ symbols) or $\mathrm{Co}(\mathrm{Salen})(\bullet$ or $\bigcirc$ symbols). Conditions: $T=30^{\circ} \mathrm{C}, V_{\mathrm{VAc}}=5 \mathrm{~mL}, \mathrm{Co}=0.10 \mathrm{mmol}, \mathrm{V}-70=0.30 \mathrm{mmol}, \mathrm{VAc} / \mathrm{Co} / \mathrm{V}-70 \mathrm{M}$ ratio of $542 / 1 / 3$, under argon.

Table 1

CMRP of nBA mediated by $\mathrm{Co}(\mathrm{acac})_{2}$ and $\mathrm{Co}(\text { Salen })^{\text {a }}$

\begin{tabular}{|c|c|c|c|c|c|c|c|}
\hline Entry & Co complex & Time (h) & Conv. (\%) & $M_{\mathrm{nSEC}}{ }^{\mathrm{c}}(\mathrm{g} / \mathrm{mol})$ & $M_{n, \text { theor }}{ }^{\mathrm{d}}(\mathrm{g} / \mathrm{mol})$ & $M_{w} / M_{n}{ }^{\mathrm{c}}$ & $f=M_{n, \text { theor }} / M_{\mathrm{nSEC}}$ \\
\hline \multirow[t]{4}{*}{1} & $\mathrm{Co}(\text { acac })_{2}$ & 0.25 & 3 & 157,000 & 3400 & 2.14 & 0.02 \\
\hline & & 0.5 & 7 & 283,400 & 7800 & 2.16 & 0.03 \\
\hline & & 0.75 & 13 & 378,700 & 14,600 & 2.07 & 0.04 \\
\hline & & 1 & 82 & 65,700 & 91,800 & 15.70 & 1.40 \\
\hline \multirow[t]{7}{*}{2} & Co(Salen) & 1.5 & 4 & 70,900 & 4500 & 1.15 & 0.06 \\
\hline & & 2 & 5 & 92,100 & 5600 & 1.15 & 0.06 \\
\hline & & 2.5 & 8 & 104,500 & 9000 & 1.17 & 0.09 \\
\hline & & 3 & 10 & 112,100 & 11,200 & 1.21 & 0.10 \\
\hline & & 3.5 & 13 & 123,400 & 14,600 & 1.28 & 0.12 \\
\hline & & 4 & 19 & 135,800 & 21,300 & 1.29 & 0.16 \\
\hline & & 4.5 & 23 & 141,100 & 25,800 & 1.38 & 0.18 \\
\hline
\end{tabular}

\footnotetext{
a Conditions: $T=30^{\circ} \mathrm{C}, n_{\mathrm{nBA}}=35.20 \mathrm{mmol}(5 \mathrm{~mL}), \mathrm{Co}=0.10 \mathrm{mmol}, \mathrm{V}-70=0.04 \mathrm{mmol}, \mathrm{nBA} / \mathrm{Co} / \mathrm{V}-70=350 / 1 / 0.4$, under argon.

${ }^{\mathrm{b}}$ Determined by ${ }^{1} \mathrm{H}$ NMR.

c Determined by SEC-THF using PS calibration.

${ }^{\mathrm{d}} M_{n, 100 \% \text { conv. }}=\left(350 \times M_{\mathrm{nBA}}\right) / 0.4=112,000 \mathrm{~g} / \mathrm{mol}, M_{n, \text { theor }}=M_{n, 100 \% \text { conv. }} \times$ conv.
}

conditions. As suggested by Wayland et al., the square planar geometry of cobalt complexes such as $\mathrm{Co}\left(\mathrm{Salen}^{*}\right)$ [80] is well-suited for controlling the radical polymerization via a DT pathway $[22,49]$. McNeil et al. reported the high efficiency of a square planar bis( $\beta$-ketoaminato)cobalt complex (Fig. 1) in controlling MA polymerization via a RT pathway using a V-70/Co ratio of 0.6/1 [70].

Considering the data above, $\mathrm{Co}(\mathrm{acac})_{2}$ appears better suited for VAc than nBA polymerization whereas $\mathrm{Co}$ (Salen) type complexes afford a better control to nBA. This observation motivates the in-situ exchange of ligands, from bidentate acac to tetradentate Salen type ligands, for the one-pot synthesis of PVAc-b-PnBA copolymers (Scheme 4).

\subsection{Acac/Salen and acac/Salen* ligand exchange for conducting CMRP of $n B A$}

Firstly, the possibility to quantitatively exchange acac ligand of cobalt(II) complex by Salen or Salen* ligand is tested by reacting stoichiometric amounts of $\mathrm{Co}(\mathrm{acac})_{2}$ with the Salen type ligand at room temperature in $\mathrm{CH}_{2} \mathrm{Cl}_{2}$ for $1 \mathrm{~h}$. The expected cobalt(II)(Salen) complexes are isolated after precipitation in pentane. Indeed, the IR spectra of the collected complexes are identical to $\mathrm{Co}(\mathrm{II})($ Salen) from commercial sources (Fig. S4) or to those reported in the literature $[81,82]$. This fast exchange reaction between bidentate and tetradentate ligands most probably consists in an entropy driven process.

Next, this exchange is tentatively carried out on an alkyl-cobalt(III) adduct $\left[\mathrm{Co}(\mathrm{acac})_{2}-\left(\left(\mathrm{CHOCOCH}_{3}\right)-\right.\right.$ $\left.\mathrm{CH}_{2}\right)_{<4}-\mathrm{R}_{0}$; alkyl-Co(acac $)_{2}$ ] [51] that mimics a PVAc-Co(acac) $)_{2}$ dormant chain (Scheme 4). The in-situ formation of alkyl-Co(Salen) and alkyl-Co(Salen*) is performed according to a similar procedure, i.e. by mixing alkyl-Co(acac $)_{2}$ with 1.2 equiv. of the corresponding ligand (Salen or Salen ${ }^{*}$ ) at room temperature in $\mathrm{CH}_{2} \mathrm{Cl}_{2}$. After few minutes, the solutions turn from red to dark green in line with a change in the coordination sphere of the metal.

After solvent elimination, the resulting alkyl-cobalt compounds are used without further purification as CMRP initiator for the bulk nBA polymerization. At $20^{\circ} \mathrm{C}$, no polymerization is observed after $3 \mathrm{~h}$ whatever the alkyl-cobalt Salen type used, in sharp contrast to alkyl- $\mathrm{Co}(\mathrm{acac})_{2}$ that leads to a highly exothermic and uncontrolled polymerization in a few minutes [71]. However, increasing the polymerization temperature to $40^{\circ} \mathrm{C}$ permits to initiate the nBA polymerization by both alkyl- $\mathrm{Co}$ (Salen) and 
Table 2

Radical polymerization of nBA initiated by in-situ formed alkyl-cobalt adducts R-Co(Salen) and R-Co(Salen*). ${ }^{\text {a }}$

\begin{tabular}{|c|c|c|c|c|c|c|}
\hline Radical initiator & Time (h) & Conv. ${ }^{\mathrm{b}}(\%)$ & $M_{\mathrm{nSEC}}{ }^{\mathrm{C}}(\mathrm{g} / \mathrm{mol})$ & $M_{n, \text { theor }}{ }^{\mathrm{d}}(\mathrm{g} / \mathrm{mol})$ & $f=M_{n, \text { theor }} / M_{\mathrm{nSEC}}$ & $M_{w} / M_{n}{ }^{\mathrm{c}}$ \\
\hline \multirow[t]{7}{*}{ R-Co(Salen) } & 0.5 & 5 & 8500 & 2100 & 0.25 & 1.10 \\
\hline & 1 & 18 & 17,700 & 7400 & 0.42 & 1.23 \\
\hline & 1.5 & 35 & 24,800 & 14,300 & 0.58 & 1.30 \\
\hline & 2 & 44 & 30,700 & 18,000 & 0.59 & 1.31 \\
\hline & 2.5 & 53 & 33,100 & 21,700 & 0.66 & 1.38 \\
\hline & 3 & 60 & 37,900 & 24,500 & 0.65 & 1.41 \\
\hline & 4 & 71 & 39,600 & 29,000 & 0.73 & 1.46 \\
\hline \multirow[t]{6}{*}{ R-Co(Salen*) } & 1 & 11 & 15,700 & 4500 & 0.29 & 1.12 \\
\hline & 2 & 20 & 22,000 & 8200 & 0.37 & 1.18 \\
\hline & 3 & 30 & 27,200 & 12,300 & 0.45 & 1.19 \\
\hline & 4 & 43 & 29,200 & 17,600 & 0.60 & 1.24 \\
\hline & 5 & 51 & 32,300 & 20,900 & 0.65 & 1.25 \\
\hline & 6 & 61 & 32,400 & 25,000 & 0.77 & 1.27 \\
\hline
\end{tabular}

a Conditions: $T=40^{\circ} \mathrm{C}, n_{\mathrm{nBA}}=35.20 \mathrm{mmol}(5 \mathrm{~mL}), \mathrm{Co}=0.11 \mathrm{mmol},[\mathrm{nBA}] /[\mathrm{Co}]=320 / 1$, under argon.

${ }^{b}$ Determined by ${ }^{1} \mathrm{H}$ NMR.

c Determined by SEC-THF using PS calibration.

${ }^{\mathrm{d}} M_{n, 100 \% \text { conv. }}=320 \times M_{\mathrm{nBA}}=41,000 \mathrm{~g} / \mathrm{mol}, M_{n, \text { theor }}=M_{n, 100 \% \text { conv. }} \times$ conv.

alkyl-Co(Salen*) (Table 2). The polymerization is faster with $\mathrm{R}-\mathrm{Co}$ (Salen) with about $70 \%$ monomer conversion after $4 \mathrm{~h}$, compared to about $40 \%$ with R-Co(Salen*) after the same period of time (Fig. 3a, Table 2). Molar masses increase almost linearly and similarly with the monomer conversion for the two experiments. Dispersities of PnBAs remain relatively low (Fig. $3 b$, Table 2 ) especially for the polymerization conducted by alkyl-Co(Salen*) $\left(M_{w} /\right.$ $\left.M_{n}<1.3\right)$. Fig. S5 shows that SEC traces are shifted towards the higher molar mass side when the conversion increases although some tailing is observed. The origin of the shoulder observed at the low molar mass side on Fig. S5b after $6 \mathrm{~h}$ of reaction is however not understood yet.

The satisfactory efficiency factor obtained with the alkyl-cobalt initiator after the ligand exchange reaction is a strong incentive to apply the same ligand exchange strategy on a PVAc- $\mathrm{Co}(\mathrm{acac})_{2}$ macroinitiator. The main goal is to exploit this ligand exchange for the synthesis of well-defined PVAc- $b$-PnBA block copolymers. Typically, a PVAc-Co(acac $)_{2}$ with low dispersity $\left(M_{w} / M_{n} \leqslant 1.07\right.$, Table S2) is prepared from the alkyl-Co(acac) $)_{2}$ [51] before the addition of 1.2 equiv. of Salen or Salen* ligand in solution in $\mathrm{CH}_{2} \mathrm{Cl}_{2}$ (Scheme 4). After solvent and residual monomer evaporation, nBA is added and the polymerization occurs in bulk at $40^{\circ} \mathrm{C}$. SEC analysis of the resulting polymer shows the production of a PVAc- $b-P n B A$ copolymer with a molar mass that increases with nBA conversion (Fig. 4). However, some PVAc macroinitiator remains unreacted during the whole polymerization process (see below). The nBA polymerization initiated by PVAc-Co(Salen) leads to copolymer with higher molar masses and dispersities compared to the copolymer produced from PVAc-Co(Salen*) (Table S2), which matches the conclusions drawn above for the nBA polymerization initiated from the in-situ generated alkyl-Co(Salen) and alkyl-Co(Salen*) complexes (Table 2). Activation of PVAc-Co(Salen*) macroinitiator is also more efficient compared to PVAC-Co(Salen) because only a low amount of unconsumed PVAc is detected with the former complex (Fig. 4). From SEC-chromatogram deconvolution, PVAc- $b-$ PnBA prepared from PVAc-Co(Salen*) after $5 \mathrm{~h}$ is contaminated by about 10\% PVAc macroinitiator (Fig. S6). Since the SEC peak of PVAc- $b$-PnBA copolymer is well resolved and does not overlap with the one of the minor fraction of unreacted chains, the dispersity of the block copolymer can be measured and is equal to 1.32 [77]. This value is
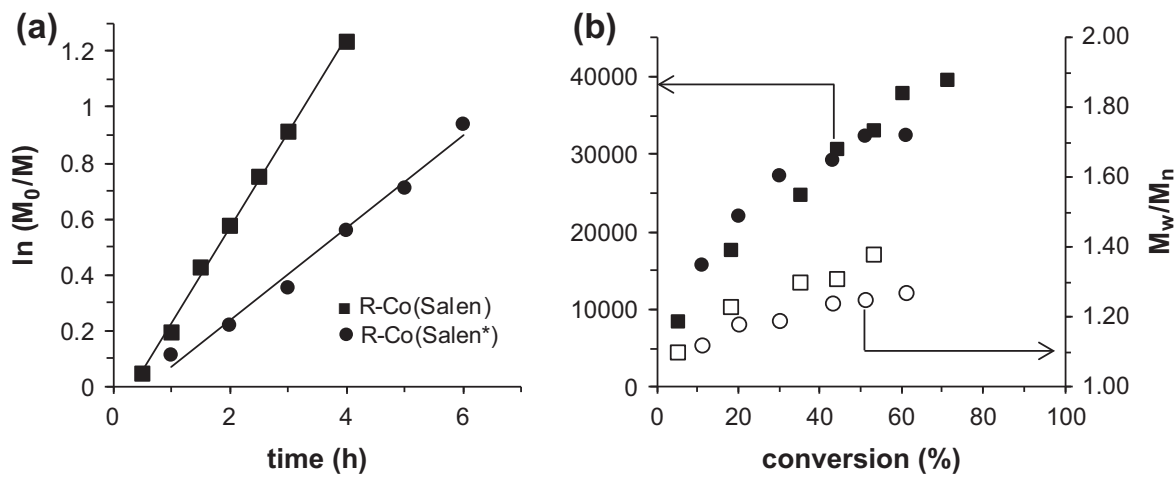

Fig. 3. Plots of $\ln \left([M]_{0} /[M]\right)$ with time (a, left) and dependence of PnBA number average molar mass with conversion (b, filled symbols) and dependence of $M_{w} / M_{n}$ with conversion (b, open symbols) for the nBA polymerization initiated by R-Co(Salen) ( $\square$ or $\square$ symbols) or R-Co(Salen $*$ ) ( or $\bigcirc$ symbols). Conditions: $T=40^{\circ} \mathrm{C}, n_{\mathrm{nBA}}=35.20 \mathrm{mmol}(5 \mathrm{~mL})$, alkyl-Co $=0.11 \mathrm{mmol},[\mathrm{nBA}] /[\mathrm{Co}]=320 / 1$, under argon. 

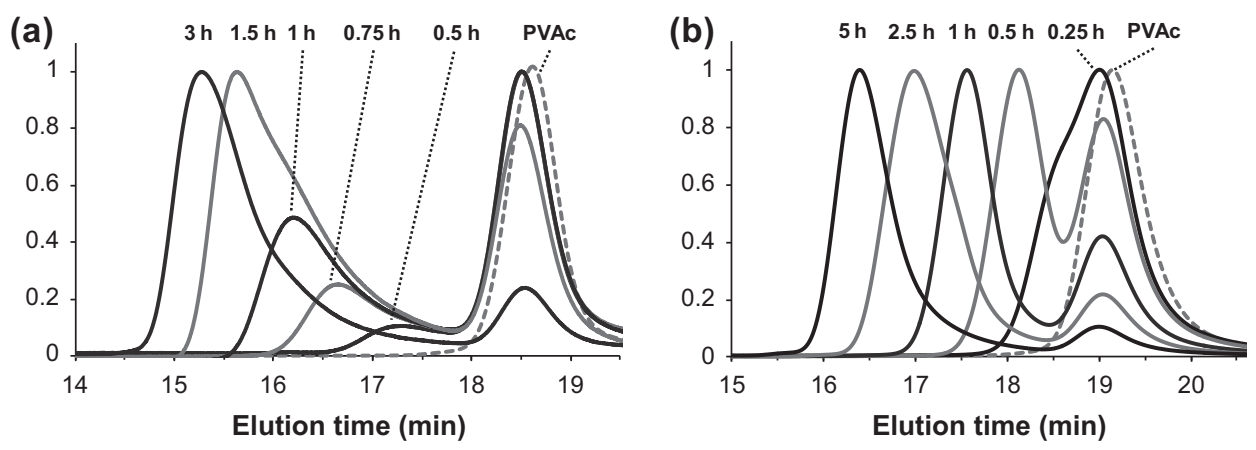

Fig. 4. Selected SEC curves of PVAc- $b$-PnBA copolymers prepared via nBA chain extension initiated by $\mathrm{PVAc}-\mathrm{Co}(\mathrm{Salen})(\mathrm{a}$, left) or $\mathrm{PVAc}-\mathrm{Co}(\mathrm{Salen} *)$ (b, right). Conditions: $T=40^{\circ} \mathrm{C}, n_{\mathrm{nBA}}=35.20 \mathrm{mmol}(5 \mathrm{~mL})$, alkyl-Co $=0.11 \mathrm{mmol}$, [nBA] $/[\mathrm{Co}]=320 / 1$, under argon; PVAc corresponds to initial macro-initiator before chain extension; molecular parameters of the corresponding polymers are presented in Table S2. (a) CMRP conducted by PVAc-Co(Salen) (left): PVAc: $M_{n}=9900 \mathrm{~g} / \mathrm{mol}, M_{w} / M_{n}=1.07$, VAc conv. $=25 \% ; 0.5 \mathrm{~h}: M_{n}=10,700 \mathrm{~g} / \mathrm{mol}, M_{w} / M_{n}=1.18, \mathrm{nBA}$ conv. $=3 \% ; 0.75 \mathrm{~h}: M_{n}=12,700 \mathrm{~g} / \mathrm{mol}, M_{w} / M_{n}=1.48$, nBA conv. $=5 \% ; 1 \mathrm{~h}: M_{n}=15,000 \mathrm{~g} / \mathrm{mol}, M_{w} / M_{n}=2.05$, nBA conv. $=8 \% ; 1.5 \mathrm{~h}: M_{n}=21,900 \mathrm{~g} / \mathrm{mol}, M_{w} / M_{n}=3.02, \mathrm{nBA}$ conv. $=15 \% ; 3 \mathrm{~h}: M_{n}=46,200 \mathrm{~g} / \mathrm{mol}, M_{w} /$ $M_{n}=3.40$, nBA conv. $=40 \%$; (b) CMRP conducted by PVAc-Co(Salen $*$ ) (right): PVAc: $M_{n}=7900 \mathrm{~g} / \mathrm{mol}, M_{w} / M_{n}=1.06$, VAc conv. $=29 \% ; 0.25 \mathrm{~h}: M_{n}=9100 \mathrm{~g} /$ mol, $M_{w} / M_{n}=1.10$, nBA conv. $=3 \% ; 0.5 \mathrm{~h}: M_{n}=10,700 \mathrm{~g} / \mathrm{mol}, M_{w} / M_{n}=1.16$, nBA conv. $=7 \% ; 1 \mathrm{~h}: M_{n}=14,100 \mathrm{~g} / \mathrm{mol}, M_{w} / M_{n}=1.31, \mathrm{nBA}$ conv. $=14 \% ; 2.5 \mathrm{~h}$ : $M_{n}=21,400 \mathrm{~g} / \mathrm{mol}, M_{w} / M_{n}=1.43, \mathrm{nBA}$ conv. $=31 \% ; 5 \mathrm{~h}: M_{n}=33,000 \mathrm{~g} / \mathrm{mol}, M_{w} / M_{n}=1.59, \mathrm{nBA}$ conv. $=56 \%$.

rather low compared to the dispersity of the PVAc- $b$-PMA copolymer prepared solely by $\mathrm{Co}\left(\right.$ Salen $\left.^{*}\right)\left(M_{w} / M_{n}=1.61\right)$ [77] or compared to PVAc- $b$-PnBA obtained by sequential $\mathrm{Co}(\mathrm{acac})_{2}$-mediated copolymerization of VAc and nBA $\left(M_{w} / M_{n}=1.70\right)$ [71]. In the latter case, the extent of unreacted PVAc macroinitiator was also much higher compared to the exchange ligand strategy presented in this work. A representative ${ }^{1} \mathrm{H}$ NMR spectrum of a PVAc- $b$-PnBA block copolymer prepared by this ligand exchange process is provided in Fig. S7.

\section{Conclusion}

The controlled radical polymerization of VAc and nBA was explored using $\mathrm{Co}$ (Salen) or $\mathrm{Co}(\mathrm{acac})_{2}$ as controlling agent in the presence of V70 as free radical initiator, in the bulk at $30^{\circ} \mathrm{C}$. $\mathrm{Co}(\mathrm{acac})_{2}$ was well-suited for the VAc polymerization but was inefficient to control the nBA polymerization. In contrast, $\mathrm{Co}$ (Salen) complex proved to be more efficient for the polymerization of nBA than VAc. Therefore, the in-situ acac/Salen exchange reaction appeared as a promising approach for expanding the scope of CMRP and particularly for synthesizing well-defined PVAc- $b$-PnBA copolymers. Successful exchange reactions took place when treating a low molar mass alkyl-Co(acac) $)_{2}$ with tetradentate Salen or Salen* ligands. In contrast to alkyl- $\mathrm{Co}(\mathrm{acac})_{2}$ that provides a very fast, exothermic and uncontrolled polymerization of nBA, the in-situ formed alkyl-Co(Salen) and alkyl-Co(Salen*) were able to initiate and control the radical polymerization of $n B A$. By carrying out this ligand exchange reaction on a PVAc- $\mathrm{Co}(\mathrm{acac})_{2}$ prepared by CMRP of VAc initiated by alkyl-Co(acac) $)_{2}$, the resulting $\mathrm{PVAc}-\mathrm{Co}$ (Salen) and PVAc-Co(Salen*) were successfully used as macro-initiators for the nBA polymerization and provided PVAc- $b$-PnBA block copolymers. Thermal activation of PVAc-Co(Salen*) was more efficient than PVAc- $\mathrm{Co}$ (Salen) and led to a PVAc- $b$-PnBA copolymer with a lower dispersity, although a tiny amount of unreacted PVAc chains remained in the final product. Although further optimizations are required, the modification of the metal center via in situ ligand exchange is a convenient and straightforward alternative for the preparation of block copolymers from monomers that are difficult or impossible to control with the same cobalt complex.

\section{Experimental section}

\subsection{General considerations}

Vinyl acetate (VAc, >99\%, Aldrich) and n-butyl acrylate (nBA, >99\%, Aldrich) were dried over calcium hydride, degassed by several freeze-pump-thaw cycles, distilled under reduced pressure and stored at $-20^{\circ} \mathrm{C}$ under argon. $N, N^{\prime}$-Bis(salicylidene)ethylenediamine (Salen, $98 \%$, Aldrich), (1R,2R)-(-)-1,2-Cyclohexanediamino- $N, N$ '-bis(3,5-di-t-butylsalicylidene)(Salen*, 98\%, Aldrich), 2,2,6,6-tetramethylpiperidine 1-oxyl (TEMPO, 98\%, Aldrich), Bis-(acetylacetonato)cobalt(II) $\left(\mathrm{Co}(\mathrm{acac})_{2},>98 \%\right.$, Acros $),\left[N, N^{\prime}\right.$-Bis(salicylidene)ethylenediamine]cobalt(II) ( $\mathrm{Co}$ (Salen), >99\%, TCI), 2,2'-azobis(4-methoxy-2,4-dimethyl valeronitrile) (V-70, Wako) were used as received.

The alkyl-cobalt(III) adduct initiator ([Co(acac) $)_{2}$ $\left.\left.\left(\left(\mathrm{CHOCOCH}_{3}\right)-\mathrm{CH}_{2}\right)_{<4}-\mathrm{R}_{0}\right)\right] ; \mathrm{R}_{0}$ being the primary radical generated by 2,2'-azo-bis(4-methoxy-2,4-dimethyl valeronitrile) (V-70, Wako) was prepared as described previously and stored as a $\mathrm{CH}_{2} \mathrm{Cl}_{2}$ solution at $-20{ }^{\circ} \mathrm{C}$ under argon [51]. All polymerizations and synthesis were performed by classical Schlenk techniques under argon using dry and degassed monomers.

\subsection{Characterization}

The molar masses $\left(M_{n}\right)$ and molar mass distributions $\left(M_{w} / M_{n}\right)$ of polymers were determined by size-exclusion chromatography (SEC) in tetrahydrofuran (THF) relative to poly(styrene) (PS) standards at $45^{\circ} \mathrm{C}$ (flow rate: $0.7 \mathrm{~mL} / \mathrm{min}$ ) with a Malvern chromatograph equipped with a Viscotek TDA 305 triple detection (refractometer, viscosimeter and low angle laser light scattering (LALLS)) as 
well as Agilent columns (three PL-gel $5 \mu \mathrm{m}$ columns: $10^{4}$, $10^{3}$ and $10^{2} \AA$ ). ${ }^{1} \mathrm{H}$ NMR spectra of reaction mixtures were recorded in $\mathrm{CDCl}_{3}$ at $298 \mathrm{~K}$ with a $250 \mathrm{MHz}$ Bruker spectrometer. IR spectra in the range of $4000-450 \mathrm{~cm}^{-1}$ were recorded in $\mathrm{KBr}$ pellets on a PerkinElmer Spectrum One FT-IR spectrometer.

\subsubsection{CMRP of VAc using $\mathrm{Co}(\mathrm{acac})_{2}$ or $\mathrm{Co}$ (Salen) as controlling agent}

Radical initiator $\mathrm{V}-70 \quad(92.5 \mathrm{mg}, \quad 0.30 \mathrm{mmol})$ and $\mathrm{Co}(\mathrm{acac})_{2}(25.7 \mathrm{mg}, 0.10 \mathrm{mmol})$ were placed in a $30 \mathrm{~mL}$ Schlenk flask and degassed by three vacuum/argon cycles. Vinyl acetate (VAc) ( $5 \mathrm{~mL}, 54.20 \mathrm{mmol}$ ) was then added by syringe under argon ([VAc] $/[\mathrm{V}-70] /[\mathrm{Co}]=542 / 3 / 1)$. The purple mixture was stirred and heated at $30^{\circ} \mathrm{C}$. No polymerization occurred for at least $18 \mathrm{~h}$, after which the viscosity of the solution increased substantially. Samples were withdrawn at different reaction times and analyzed by ${ }^{1} \mathrm{H}$ NMR to determine monomer conversion and by SEC-THF for molecular parameters using PS calibration, after addition of TEMPO to neutralize radicals [51]. The same procedure was followed for VAc polymerization using $\mathrm{Co}$ (Salen) (32.5 mg, $0.10 \mathrm{mmol}$ ) as controlling agent.

\subsubsection{CMRP of $n B A$ using $\mathrm{Co}$ (acac $)_{2}$ or $\mathrm{Co}$ (Salen) as controlling agent}

Radical initiator $\mathrm{V}-70 \quad(12.3 \mathrm{mg}, \quad 0.04 \mathrm{mmol})$ and $\mathrm{Co}(\mathrm{acac})_{2}(25.7 \mathrm{mg}, 0.10 \mathrm{mmol})$ were placed in a $30 \mathrm{~mL}$ Schlenk flask and degassed by three vacuum/argon cycles. Pure n-Butyl acrylate (nBA) $(5 \mathrm{~mL}, 35.00 \mathrm{mmol})$ was then added by syringe under argon ([nBA]/[V-70]/[Co] $=350 /$ $0.4 / 1)$. The purple mixture was stirred and heated at $30^{\circ} \mathrm{C}$. Samples were withdrawn at different reaction times to determine monomer conversion by ${ }^{1} \mathrm{H}$ NMR and molecular parameters by SEC-THF using PS calibration after addition of TEMPO. The same procedure was followed for nBA polymerization using $\mathrm{Co}$ (Salen) $(32.5 \mathrm{mg}, 0.10 \mathrm{mmol})$ as controlling agent.

\subsubsection{Synthesis of $\mathrm{Co}$ (Salen) or $\mathrm{Co}\left(\right.$ Salen $\left.^{*}\right)$}

$\mathrm{Co}(\mathrm{acac})_{2} \quad(113.0 \mathrm{mg}, 0.44 \mathrm{mmol})$ was placed in a Schlenk flask and degassed by three vacuum/argon cycles. A volume of $1.5 \mathrm{~mL}$ of $\mathrm{CH}_{2} \mathrm{Cl}_{2}$ was added under argon and a solution of Salen ligand ( $118.0 \mathrm{mg}, 0.44 \mathrm{~mol}$ ) in $2 \mathrm{~mL}$ of $\mathrm{CH}_{2} \mathrm{Cl}_{2}$ was injected into the suspension under argon. The reaction mixture turned to red and was stirred at room temperature for $1 \mathrm{~h}$. Complex $\mathrm{Co}$ (Salen) was precipitated with addition of $40 \mathrm{~mL}$ of pentane, recovered by centrifugation and dry overnight at $40{ }^{\circ} \mathrm{C}$ under vacuum. The complex was analyzed by IR using $\mathrm{KBr}$ (Fig. S4a): 3051 (w), 3019 (w), 2920 (w), 1634 (S), 1600 (S), 1532 (m), 1467 (m), 1449 (S), 1347 (S), 1329 (m), 1273 (m), 1198 (m), $1146(\mathrm{~m}), 1127(\mathrm{~m}), 753(\mathrm{~m}), 735(\mathrm{~m}) \mathrm{cm}^{-1}$.

Complex $\mathrm{Co}($ Salen*) was synthesized following the same method than $\mathrm{Co}$ (Salen) by reacting Salen* $(31.5 \mathrm{mg}$, $0.06 \mathrm{mmol})$ and $\mathrm{Co}(\mathrm{acac})_{2}(15.0 \mathrm{mg}, 0.06 \mathrm{mmol})$ and characterized by IR in $\mathrm{KBr}$ (Fig. S4b): 2949 (VS), 2864 (S), 1634 (m), 1595 (S), 1526 (S), 1461 (m), 1432 (m), 1385 (m), 1359 (m), 1337 (m), 1320 (m), 1253 (S), 1201 (w), $1175(\mathrm{~S}), 929(\mathrm{~m}), 867(\mathrm{~m}), 834(\mathrm{~m}), 786(\mathrm{~m}), 746(\mathrm{w})$, $639(\mathrm{w}) \mathrm{cm}^{-1}$.
No characteristic signal of $\mathrm{Co}(\text { acac })_{2}$ (1590 (S), 1514 (S), 1396 (S), $1257(\mathrm{~S}), 1020(\mathrm{~m}), 920(\mathrm{~m}) \mathrm{cm}^{-1}$ ) was detected by IR (Fig. S4).

\subsubsection{Polymerization of $n B A$ initiated by alkyl-Co(Salen) or alkyl-Co(Salen $\left.{ }^{*}\right)$ \\ Ligand Salen ( $39 \mathrm{mg}, 0.14 \mathrm{mmol}$ ) was placed in a $30 \mathrm{~mL}$} Schlenk flask and degassed by three vacuum/argon cycles. A volume of $5 \mathrm{~mL}$ of dry and degassed $\mathrm{CH}_{2} \mathrm{Cl}_{2}$ was added under argon and then a solution of alkyl-cobalt(III) initiator [51] in $\mathrm{CH}_{2} \mathrm{Cl}_{2}(1.0 \mathrm{~mL}$ of a $0.11 \mathrm{M}$ stock solution, $0.11 \mathrm{mmol}$ ) was introduced under argon in the $30 \mathrm{~mL}$ Schlenk tube. The red solution was stirred at room temperature and turned to dark green after a couple of minutes. After $1 \mathrm{~h}$, all volatiles were evaporated to dryness under reduced pressure at room temperature. A volume of $5 \mathrm{~mL}$ of dry and degassed nBA was added under argon and then the dark green solution was stirred at $40{ }^{\circ} \mathrm{C}$. The viscosity of the solution increased substantially after a couple of minutes and samples were withdrawn at different reaction times to determine monomer conversion by ${ }^{1} \mathrm{H}$ NMR and molecular parameters by SEC using PS calibration after addition of TEMPO.

The same procedure was followed for nBA polymerization initiated by alkyl-Co(Salen*) after reaction of Salen* ligand (72.0 mg, $0.13 \mathrm{mmol})$ with alkyl-Co(acac) $)_{2}$ adduct (0.11 mmol).

\subsubsection{Preparation of PVAc- $\mathrm{Co}(\text { acac })_{2}$}

A solution of alkyl-cobalt(III) initiator [51] in $\mathrm{CH}_{2} \mathrm{Cl}_{2}$ was introduced under argon in the $30 \mathrm{~mL}$ Schlenk flask $(1.0 \mathrm{~mL}$ of a $0.11 \mathrm{M}$ stock solution, $0.11 \mathrm{mmol})$ and evaporated to dryness under reduced pressure at room temperature. A volume of $5 \mathrm{~mL}$ of VAc was added and the reaction mixture was stirred at $40{ }^{\circ} \mathrm{C}$ for $9 \mathrm{~h}$. At the end of the polymerization, an aliquot was withdrawn to determine the monomer conversion by ${ }^{1} \mathrm{H}$ NMR (conversion: $25 \%$ and $29 \%$ for PVAc-Co(Salen) and PVAc-Co(Salen*), respectively) and the molecular parameters by SEC after addition of TEMPO $\left(M_{n}=9900, M_{w} / M_{n}=1.07\right.$ for PVAc-Co(Salen); $M_{n}=7900, M_{w} / M_{n}=1.06$ for PVAc-Co(Salen*), Table S2). All volatiles were removed under reduced pressure at room temperature and the resulting PVAc- $\mathrm{Co}(\mathrm{acac})_{2}$ was stored at $-20^{\circ} \mathrm{C}$ before further manipulations. No residual VAC was detected by ${ }^{1} \mathrm{H}$ NMR during the next experiments using PVAc- $\mathrm{Co}(\text { acac })_{2}$ macroinitiator.

\subsubsection{Synthesis of PVAc- $b-P n B A$ using PVAc-Co(Salen) or PVAc-Co(Salen*) macroinitiators}

Ligand Salen ( $39 \mathrm{mg}, 0.14 \mathrm{mmol}$ ) was placed in a $30 \mathrm{~mL}$ Schlenk flask and degassed by three vacuum/argon cycles and then $8 \mathrm{~mL}$ of dry and degassed $\mathrm{CH}_{2} \mathrm{Cl}_{2}$ was added under argon. The resulting yellow solution was transferred using cannula into a Schlenk flask containing the PVAc-Co(acac $)_{2}$ previously prepared $(0.11 \mathrm{mmol}$, $M_{n}=9900 \mathrm{~g} / \mathrm{mol}, M_{w} / M_{n}=1.07$, Table S2). The red solution was stirred at room temperature and turned to dark green after a couple of minutes. After $1 \mathrm{~h}$, all volatiles were evaporated to dryness under reduced pressure at room temperature. A volume of $5 \mathrm{~mL}$ of nBA was added under argon and then the dark green solution was stirred at $40{ }^{\circ} \mathrm{C}$. Samples 
were withdrawn at different reaction times to determine monomer conversion by ${ }^{1} \mathrm{H}$ NMR and molecular parameters by SEC-THF using PS calibration after addition of TEMPO. Polymerization was stopped when the reaction medium was too viscous to withdrawn samples under argon. Results are summarized in Table S2 and Fig. 4.

The same procedure was followed for the synthesis of PVAc- $b$-PnBA initiated by PVAc-Co(Salen*) after reaction of Salen* ligand $(72.0 \mathrm{mg}, 0.13 \mathrm{mmol}) \quad$ with PVAc-Co(acac $)_{2}$ adduct $\left(0.11 \mathrm{mmol}, M_{n}=7900 \mathrm{~g} / \mathrm{mol}\right.$, $M_{w} / M_{n}=1.06$, Table S2). Results are summarized in Table S2 and Fig. 4, and a ${ }^{1} \mathrm{H}$ NMR spectrum of the resulting PVAc- $b$-PnBA copolymer after monomer elimination under reduced pressure is shown in Fig. S7.

\section{Acknowledgments}

The authors are grateful to the "Fonds National de la Recherche Scientifique (FRS-FNRS) and to the Belgian Science Policy for financial support in the frame of the Interuniversity Attraction Poles Programme (PAI VII/5) Functional Supramolecular Systems for financial support. A.D. and A.K. are grateful for fundings from the University of Liège via the "Fonds spéciaux pour la recherche - crédits de démarrage" and the FRS-FNRS for funding the MIS research project "Organo-cobalt as clean source of radicals" (convention $\mathrm{n}^{\circ} \mathrm{F} .4511 .12$ ). A.D. and C.D. are FRS-FNRS Associate Researcher and Research Director, respectively.

\section{Appendix A. Supplementary material}

Supplementary data associated with this article can be found, in the online version, at http://dx.doi.org/10.1016/ j.eurpolymj.2014.08.003.

\section{References}

[1] Ouchi M, Terashima T, Sawamoto M. Transition metal-catalyzed living radical polymerization: toward perfection in catalysis and precision polymer synthesis. Chem Rev 2009;109(11):4963-5050.

[2] Perrier S, Takolpuckdee P. Macromolecular design via reversible addition-fragmentation chain transfer (RAFT)/xanthates (MADIX) polymerization. J Polym Sci, Part A: Polym Chem 2005;43(22):5347-93.

[3] Sciannamea V, Jérôme R, Detrembleur C. In-situ nitroxide-mediated radical polymerization (NMP) processes: their understanding and optimization. Chem Rev 2008:108:1104-26.

[4] Yamago S. Precision polymer synthesis by degenerative transfer controlled/living radical polymerization using organotellurium, organostibine, and organobismuthine chain-transfer agents. Chem Rev 2009;109(11):5051-68.

[5] Destarac M. On the critical role of RAFT agent design in reversible addition-fragmentation chain transfer (RAFT) polymerization. Polym Rev 2011;51(2):163-87.

[6] Debuigne A, Hurtgen M, Detrembleur C, Jérôme C, Barner-Kowollik C, Junkers T. Interpolymer radical coupling: a toolbox complementary to controlled radical polymerization. Prog Polym Sci 2012;37:1004-30.

[7] Moad G, Rizzardo E, Thang SH. Living radical polymerization by the RAFT process - a third update. Aust J Chem 2012;65(8):985-1076.

[8] Nicolas J, Guillaneuf Y, Lefay C, Bertin D, Gigmes D, Charleux B. Nitroxide-mediated polymerization. Prog Polym Sci 2013;38(1): $63-235$.

[9] Rosen BM, Percec V. Single-electron transfer and single-electron transfer degenerative chain transfer living radical polymerization. Chem Rev 2009;109(11):5069-119.

[10] di Lena F, Matyjaszewski K. Transition metal catalysts for controlled radical polymerization. Prog Polym Sci 2010;35(8):959-1021.
[11] Allan LEN, Perry MR, Shaver MP. Organometallic mediated radica polymerization. Prog Polym Sci 2012;37(1):127-56.

[12] Debuigne A, Poli R, Jérôme C, Jérôme R, Detrembleur C. Overview of cobalt-mediated radical polymerization: roots, state of the art and future prospects. Prog Polym Sci 2009;34(3):211-39.

[13] Matyjaszewski K. Comparison and classification of controlled/living radical polymerizations. ACS Symp Ser 2000;768:2-26.

[14] Tsarevsky NV. Catalytic activity and performance of copper-based complexes mediating atom transfer radical polymerization. Isr J Chem 2012;52(3-4):276-87.

[15] Bai L, Zhang L, Cheng Z, Zhu X. Activators generated by electron transfer for atom transfer radical polymerization: recent advances in catalyst and polymer chemistry. Polym Chem 2012;3(10):2685-97.

[16] Tsarevsky NV, Matyjaszewski K. "Green" atom transfer radical polymerization: from process design to preparation of welldefined environmentally friendly polymeric materials. Chem Rev 2007;107(6):2270-99.

[17] Hurtgen M, Detrembleur C, Jérôme C, Debuigne A. Insight into organometallic-mediated radical polymerization. Polym Rev 2011;51:188-213.

[18] Poli R. Relationship between one-electron transition-metal reactivity and radical polymerization processes. Angew Chem Int Ed 2006;45(31):5058-70.

[19] Tang H, Arulsamy N, Radosz M, Shen Y, Tsarevsky NV, Braunecker WA, et al. Highly active copper-based catalyst for atom transfer radical polymerization. J Am Chem Soc 2006;128(50):16277-85.

[20] Tang W, Kwak Y, Braunecker W, Tsarevsky NV, Coote ML, Matyjaszewski K. Understanding atom transfer radical polymerization: effect of ligand and initiator structures on the equilibrium constants. J Am Chem Soc 2008;130(32):10702-13.

[21] Matyjaszewski K. Atom transfer radical polymerization (ATRP): current status and future perspectives. Macromolecules 2012;45(10):4015-39.

[22] Poli R. Radical coordination chemistry and its relevance to metalmediated radical polymerization. Eur J Inorg Chem 2011;10:1513-30.

[23] Moineau G, Minet M, Dubois P, Teyssié P, Senninger T, Jérôme R. Controlled radical polymerization of (Meth)acrylates by ATRP with NiBr 2(PPh3)2 as catalyst. Macromolecules 1999;32(1):27-35.

[24] Kabachii YA, Kochev SY, Bronstein LM, Blagodatskikh IB, Valetsky PM. Atom transfer radical polymerization with Ti(III) halides and alkoxides. Polym Bull 2003;50(4):271-8.

[25] Asandei AD, Moran IW. TiCp2Cl-catalyzed living radical polymerization of styrene initiated by oxirane radical ring opening. J Am Chem Soc 2004;126(49):15932-3.

[26] Le Grognec E, Claverie J, Poli R. Radical polymerization of styrene controlled by half-sandwich $\mathrm{Mo}(\mathrm{III}) / \mathrm{Mo}(\mathrm{IV})$ couples: all basic mechanisms are possible. J Am Chem Soc 2001;123(39):9513-24.

[27] Stoffelbach F, Poli R, Richard P. Half-sandwich molybdenum(III) compounds containing diazadiene ligands and their use in the controlled radical polymerization of styrene. J Organomet Chem 2002;663(1-2):269-76.

[28] Braunecker WA, Brown WC, Morelli BC, Tang W, Poli R, Matyjaszewski K. Origin of activity in $\mathrm{Cu}-, \mathrm{Ru}-$, and Os-mediated radical polymerization. Macromolecules 2007;40(24):8576-85.

[29] Braunecker WA, Itami Y, Matyjaszewski K. Osmium-mediated radical polymerization. Macromolecules 2005;38(23):9402-4.

[30] Weiser M-S, Muelhaupt R. Cobalt(II) octanoate and cobalt(II) perfluorooctanoate catalyzed atom transfer radical polymerization of styrene in toluene and fluorous media-a versatile route to catalyst recycling and oligomer formation. J Polym Sci, Part A: Polym Chem 2005;43(17):3804-13.

[31] Kotani Y, Kamigaito M, Sawamoto M. Re(V)-mediated living radical polymerization of styrene:1 ReO2I(PPh3)2/R-I initiating systems. Macromolecules 1999;32(8):2420-4.

[32] Matyjaszewski K, Xia J. Atom transfer radical polymerization. Chem Rev 2001;101:2921-90.

[33] Simal F, Demonceau A, Noels AF. Highly efficient ruthenium-based catalytic systems for the controlled free-radical polymerization of vinyl monomers. Angew Chem Int Ed 1999;38(4):538-40.

[34] Delaude L, Delfosse S, Richel A, Demonceau A, Noels AF. Tuning of ruthenium N-heterocyclic carbene catalysts for ATRP. Chem Commun 2003;13:1526-7.

[35] Drozdzak R, Allaert B, Ledoux N, Dragutan I, Dragutan V, Verpoort F. Ruthenium complexes bearing bidentate Schiff base ligands as efficient catalysts for organic and polymer syntheses. Coord Chem Rev 2005;249(24):3055-74.

[36] Matyjaszewski K, Coca S, Gaynor SG, Wei M, Woodworth BE Zerovalent metals in controlled/"living" radical polymerization. Macromolecules 1997;30(23):7348-50. 
[37] Louie J, Grubbs RH. Highly active iron imidazolylidene catalysts for atom transfer radical polymerization. Chem Commun 2000;16:1479-80.

[38] Gibson VC, O'Reilly RK, Wass DF, White AJP, Williams DJ. Polymerization of methyl methacrylate using four-coordinate $(\alpha-$ diimine)iron catalysts: atom transfer radical polymerization vs. catalytic chain transfer. Macromolecules 2003;36(8):2591-3.

[39] O'Reilly RK, Gibson VC, White AJP, Williams DJ. Design of highly active iron-based catalysts for atom transfer radical polymerization: tridentate salicylaldiminato ligands affording near ideal nernstian behavior. J Am Chem Soc 2003;125(28):8450-1.

[40] Wang J-S, Matyjaszewski K. Controlled/“living” radical polymerization. Atom transfer radical polymerization in the presence of transition-metal complexes. J Am Chem Soc 1995;117(20):5614-5.

[41] Matyjaszewski K, Patten TE, Xia J. Controlled/“living” radical polymerization. Kinetics of the homogeneous atom transfer radical polymerization of styrene. J Am Chem Soc 1997;119(4):674-80.

[42] Patten TE, Xia J, Abernathy T, Matyjaszewski K. Polymers with very low polydispersities from atom transfer radical polymerization. Science 1996;272(5263):866-8.

[43] Patten TE, Matyjaszewski K. Copper(I)-catalyzed atom transfer radical polymerization. Acc Chem Res 1999;32(10):895-903.

[44] Ayres N. Atom transfer radical polymerization: a robust and versatile route for polymer synthesis. Polym Rev 2011;51(2):138-62.

[45] Wayland BB, Poszmik G, Mukerjee SL, Fryd M. Living radical polymerization of acrylates by organocobalt porphyrin complexes. J Am Chem Soc 1994;116(17):7943-4.

[46] Debuigne A, Caille J-R, Jérôme R. Highly efficient cobalt-mediated radical polymerization of vinyl acetate. Angew Chem Int Ed 2005;44:1101-4.

[47] Greuel MP, Arvanitopoulos LD, Harwood HJ. Cobaloxime photoinitiators for free radical polymerization. USA: University of Akron; 1995. p. 18

[48] Davis TP, Kukulj D, Haddleton DM, Maloney DR. Cobalt-mediated free-radical polymerization of acrylic monomers. Trends Polym Sci 1995;3(11):365-73.

[49] Wayland BB, Peng C-H, Fu X, Lu Z, Fryd M. Degenerative transfer and reversible termination mechanisms for living radical polymerizations mediated by cobalt porphyrins. Macromolecules 2006;39(24):8219-22.

[50] Peng C-H, Fryd M, Wayland BB. Organocobalt mediated radical polymerization of acrylic acid in water. Macromolecules 2007;40(19):6814-9.

[51] Debuigne A, Champouret Y, Jérôme R, Poli R, Detrembleur C. Mechanistic insights into the cobalt-mediated radical polymerization (CMRP) of vinyl acetate with cobalt(III) adducts as initiators. Chem - Eur J 2008;14(13):4046-59.

[52] Hsu C-S, Yang T-Y, Peng C-H. Vinyl acetate living radical polymerization mediated by cobalt porphyrins: kineticmechanistic studies. Polym Chem 2014;5(12):3867-75.

[53] Kumar KSS, Gnanou Y, Champouret Y, Daran J-C, Poli R. Radical polymerization of vinyl acetate with bis(tetramethylheptanedionate)cobalt(II): coexistence of three different mechanisms. Chem - Eur J 2009;15(19):4874-85.

[54] Smith KM, McNeil WS, Abd-El-Aziz AS. Organometallic-mediated radical polymerization: developing well-defined complexes for reversible transition metal-alkyl bond homolysis. Macromol Chem Phys 2010:211(1):10-6.

[55] Wayland BB, Basickes L, Mukerjee S, Wei M, Fryd M. Living radical polymerization of acrylates initiated and controlled by organocobalt porphyrin complexes. Macromolecules 1997;30(26):8109-12.

[56] Lu Z, Fryd M, Wayland BB. New life for living radical polymerization mediated by cobalt(II) metalloradicals. Macromolecules 2004;37(8):2686-7.

[57] Langlotz BK, Fillol JL, Gross JH, Wadepohl H, Gade LH. Living radical polymerization of acrylates mediated by 1,3-bis(2-pyridylimino)isoindolatocobalt(II) complexes: monitoring the chain growth at the metal. Chem - Eur J 2008;14(33):10267-79.

[58] Debuigne A, Caille J-R, Jérôme R. Synthesis of end-functional poly(vinyl acetate) by cobalt-mediated radical polymerization. Macromolecules 2005;38(13):5452-8.

[59] Morin AN, Detrembleur C, Jérôme C, De TP, Poli R, Debuigne A. Effect of head-to-head addition in vinyl acetate controlled radical polymerization: why Is $\mathrm{Co}(\mathrm{acac}) 2$-mediated polymerization so much better? Macromolecules 2013;46(11):4303-12.

[60] Allaoua I, Goi BE, Obadia MM, Debuigne A, Detrembleur C, Drockenmuller E. (Co)Polymerization of vinyl levulinate by cobaltmediated radical polymerization and functionalization by ketoxime click chemistry. Polym Chem 2014;5(8):2973-9.
[61] Detrembleur C, Debuigne A, Hurtgen M, Jérôme C, Pinaud J, Fèvre M, et al. Synthesis of 1-vinyl-3-ethylimidazolium-based ionic liquid (Co)polymers by cobalt-mediated radical polymerization. Macromolecules 2011;44(16):6397-404.

[62] Debuigne A, Willet N, Jérôme R, Detrembleur C. Amphiphilic poly(vinyl acetate)-b-poly(N-vinylpyrrolidone) and novel double hydrophilic poly(vinyl alcohol)-b-poly( $\mathrm{N}$-vinylpyrrolidone) block copolymers prepared by cobalt-mediated radical polymerization. Macromolecules 2007;40(20):7111-8.

[63] Hurtgen M, Liu J, Debuigne A, Jérôme C, Detrembleur C. Synthesis of thermo-responsive poly(N-vinylcaprolactam)-containing block copolymers by cobalt-mediated radical polymerization. J Polym Sci, Part A: Polym Chem 2012;50:400-8.

[64] Debuigne A, Morin AN, Kermagoret A, Piette Y, Detrembleur C, Jérôme C, et al. Key role of intramolecular metal chelation and hydrogen bonding in the cobalt-mediated radical polymerization of N-vinyl amides. Chem - Eur J 2012;18:12834-44.

[65] Kermagoret A, Fustin C-A, Bourguignon M, Detrembleur C, Jérôme C, Debuigne A. One-pot controlled synthesis of double thermoresponsive $\mathrm{N}$-vinylcaprolactam-based copolymers with tunable LCSTs. Polym Chem 2013;4(8):2575-83.

[66] Kermagoret A, Debuigne A, Jérôme C, Detrembleur C. Precision design of ethylene- and polar-monomerbased copolymers by organometallic-mediated radical polymerization. Nat Chem 2014;6:179-84.

[67] Maria S, Kaneyoshi H, Matyjaszewski K, Poli R. Effect of electron donors on the radical polymerization of vinyl acetate mediated by [Co(acac)2]: degenerative transfer versus reversible homolytic cleavage of an organocobalt(III) complex. Chem - Eur J 2007;13(9):2480-92.

[68] Debuigne A, Michaux C, Jérôme C, Jérôme R, Poli R, Detrembleur C. Cobalt-mediated radical polymerization of acrylonitrile: kinetics investigations and DFT calculations. Chem - Eur J 2008;14:7623-37.

[69] Li S, Bruin Bd, Peng C-H, Fryd M, Wayland BB. Exchange of organic radicals with organo-cobalt complexes formed in the living radical polymerization of vinyl acetate. J Am Chem Soc 2008;130(40):13373-81.

[70] Sherwood RK, Kent CL, Patrick BO, McNeil WS. Controlled radical polymerisation of methyl acrylate initiated by a well-defined cobalt alkyl complex. Chem Commun 2010;46(14):2456-8.

[71] Hurtgen M, Debuigne A, Jérôme C, Detrembleur C. Solving the problem of bis(acetylacetonato)cobalt(II)-mediated radical polymerization (CMRP) of acrylic esters. Macromolecules 2010;43:886-94.

[72] Kumar KSS, Li Y, Gnanou Y, Baisch U, Champouret Y, Poli R, et al. Electronic and steric ligand effects in the radical polymerization of vinyl acetate mediated by $\beta$-ketoiminate complexes of cobalt(II). Chem - Asian J 2009;4(8):1257-65.

[73] Qi X-J, Li Z, Fu Y, Guo Q-X, Liu L. Anti-spin-delocalization effect in Co-C bond dissociation enthalpies. Organometallics 2008;27(12):2688-98.

[74] Li G, Zhang FF, Chen H, Yin HF, Chen HL, Zhang SY, Determination of $\mathrm{Co}-\mathrm{C}$ bond dissociation energies for organocobalt complexes related to coenzyme B12 using photoacoustic calorimetry. J Chem Soc, Dalton Trans 2002:1:105-10.

[75] Svidchenko EA, Sigan AL, Kuznetsov AA. Photoinitiated controlled radical polymerization of vinyl acetate in the presence of the CoII(Salen) complex. Dokl Chem 2014;454(2):32-5.

[76] Peng C-H, Scricco J, Li S, Fryd M, Wayland BB. Organo-cobalt mediated living radical polymerization of vinyl acetate. Macromolecules 2008;41(7):2368-73.

[77] Liao C-M, Hsu C-C, Wang F-S, Wayland BB, Peng C-H. Living radical polymerization of vinyl acetate and methyl acrylate mediated by Co(Salen*) complexes. Polym Chem 2013;4(10):3098-104.

[78] Debuigne A, Poli R, Jérôme R, Jérôme C, Detrembleur C. Key role of metal-coordination in cobalt-mediated radical polymerization of vinyl acetate. ACS Symp Ser 2009;1024:131-47.

[79] Darensbourg DJ. Making plastics from carbon dioxide: Salen metal complexes as catalysts for the production of polycarbonates from epoxides and $\mathrm{CO}_{2}$. Chem Rev 2007;107:2388-410.

[80] Chiang L, Allan LEN, Alcantara J, Wang MCP, Storr T, Shaver MP. Tuning ligand electronics and peripheral substitution on cobalt Salen complexes: structure and polymerisation activity. Dalton Trans 2014;43:4295-304.

[81] Kumar DN, Garg BS. Some new cobalt(II) complexes synthesis, characterization and thermal studies. I Therm Anal Cal 2002;69:607-16.

[82] Yang H, Zhang L, Su W, Yang Q, Li C. Asymmetric ring-opening of epoxides on chiral Co(Salen) catalyst synthesized in SBA-16 through the "ship in a bottle" strategy. J Catal 2007;248(2):204-12. 